\title{
PERTUMBUHAN DAN HASIL TANAMAN TOMAT (Lycopersicum esculentum MILL.) PADA PEMBERIAN PUPUK ZN DAN JARAK TANAM YANG BERBEDA
}

\author{
(Growth and Yield of Tomato (Lycopersicum esculentum Mill.) on Zn Fertilizer and \\ Different Plant Spacing)
}

\author{
Alvera Prihatini Dewi Nazari ${ }^{1}$, Rusdiansyah ${ }^{2}$, Ary Puja Meklin Siregar ${ }^{3,}$ Abdul Rahmi $^{4}$ \\ ${ }^{1,2}$ Program Studi Agroekoteknologi, Fakultas Pertanian, Universitas Mulawarman. Jl. Pasir Balengkong, \\ Kampus Gunung Kelua, Samarinda 75119, Kalimantan Timur, Indonesia. \\ Email: alverapdn@gmail.com; rrida_rusdi@yahoo.co.id \\ ${ }^{3}$ Mahasiswa Program Studi Agroekoteknologi, Fakultas Pertanian, Universitas Mulawarman. \\ Jl. Pasir Balengkong, Kampus Gunung Kelua, Samarinda 75119, Kalimantan Timur, Indonesia. \\ Email: arypuja7@gmail.com \\ ${ }^{4}$ Program Studi Agroteknologi, Fakultas Pertanian, Universitas 17 Agustus 1945 Samarinda \\ Email :rahmi_untag@yahoo.co.id
}

Article Submitted : 04-4-2020

Article Accepted : 05-9-2020

\begin{abstract}
Tomato (Lycopersicum esculentum Mill.) is a plant that is rich in benefits, but the yield is still low, some of which are due to a lack of nutrients, one of which is micronutrient zinc, and improper plant spacing. The research was carried out to determine: 1) the best dose of $\mathrm{Zn}$ fertilizer and the right plant spacing; 2) the interaction between $\mathrm{Zn}$ fertilizer dosage and plant spacing; 3) the relationship (correlation) between the two observed variables. The research was conducted from July to October 2018 in Teluk Dalam Village, Mulawarman Village, Tenggarong Seberang District, Kutai Kartanegara Regency. The $4 \times 3$ factorial experiment was arranged in a Randomized Complete Block Design with three replications. The first factor was the dose of $\mathrm{Zn}$ fertilizer, consisting of four levels, namely $0.00 ; 3.00 ; 6.00$; and $9.00 \mathrm{~kg} \mathrm{Zn} \mathrm{ha}{ }^{-1}$. The second factor was plant spacing, consisting of: $50 \mathrm{~cm} \times 50 \mathrm{~cm} ; 60 \mathrm{~cm} \times 50 \mathrm{~cm} ; 70 \mathrm{~cm} \times 50 \mathrm{~cm}$. Data were analyzed using analysis of variance, followed by the LSD test at the 5\% level. Correlation analysis was used to determine the relationship between two quantitative variables. The results showed that the effect of $\mathrm{Zn}$ fertilizer dosage was significantly different on plant height and plant age at first harvest, several fruits per plant, fruit fresh weight per plant, harvest frequency, and fruit fresh weight per hectare, but not significantly different on plant height and age plants at flowering and the number of branches per plant. The effect of plant spacing was significantly different, on the other hand, the interaction was not significantly different on all observed variables. The best dose of $\mathrm{Zn}$ fertilizer is $6.00 \mathrm{~kg} \mathrm{ha}^{-1}$ with fruit fresh weight $25.16 \mathrm{Mg} \mathrm{ha}^{-1}$ and the best plant spacing is $70 \mathrm{~cm}$ x $50 \mathrm{~cm}$ with fruit fresh weight $25.18 \mathrm{Mg} \mathrm{ha}^{-1}$. The results of the correlation analysis showed that fruit fresh weight per hectare had a positive correlation with the number of fruits, fruit fresh weight per plant, and the frequency of harvest with the correlation coefficient (r), respectively $0.7350 ; 0.8190$; and 0.6316 , but negatively correlated with plant age at flowering and first harvest, namely -0.2552 and -0.3292 .
\end{abstract}

Keywords: Plant Spacing, Tomato, Zinc. 


\section{PENDAHULUAN}

Tomat (Lycopersicum esculentum Mill.) merupakan tanaman hortikultura yang sangat dikenal masyarakat dan mempunyai banyak manfaat, baik sebagai sayuran, bahan baku industri obat-obatan dan kosmetik, maupun sebagai bahan baku pengolahan makanan. Rasa buah tomat yang manis-manis asam memberikan kesegaran pada tubuh dan cita rasa yang berbeda dibandingkan dengan buahbuah lain merupakan ciri khas yang digemari oleh hampir seluruh lapisan masyarakat. Disamping itu, buah tomat mengandung gizi yang tinggi, yaitu vitamin $\mathrm{A}$, vitamin $\mathrm{C}$, protein, karbohidrat, kalsium, natrium, kalium, fosfor, tiamin, riboflavin, niasin, dan askorbik (Cahyono, 2000).

Produktivitas tomat di Kalimantan Timur dari tahun 2015 sampai dengan tahun 2017 cenderung berfluktuasi dan mengalami penurunan, yaitu berturut-turut 10,20; 7,59; dan $8,23 \mathrm{Mg} \mathrm{ha}^{-1}$, lebih rendah dibandingkan produktivitas nasional yang mencapai 16,09 ; 15,31; dan 17,31 $\mathrm{Mg} \mathrm{ha}^{-1}$ pada kisaran waktu yang sama (Kementerian Pertanian, 2020). Produktivitas tomat yang rendah disebabkan oleh beberapa faktor, diantaranya iklim, tingkat kesuburan tanah, pengaturan jarak tanam yang tidak tepat, dan serangan hama dan penyakit (Sulthon, dkk., 2018).

Salah satu faktor penyebab rendahnya produktivitas tomat yang berkaitan dengan tanah adalah jenis tanah yang didominasi oleh tanah Ultisol. Menurut Prasetyo dan Suriadikarta (2006), jenis tanah ini mendominasi sebagian besar tanah di Indonesia dengan luas mencapai 45.794 .000 ha atau sekitar $25 \%$ dari total luas daratan Indonesia, dengan sebaran terluas di Kalimantan, yaitu 21.938 .000 ha. Karakteristik tanah Ultisol diantaranya adalah peka terhadap erosi, bereaksi masam, serta kesuburan tanah dan kandungan bahan organik yang rendah.

Selama ini upaya yang dilakukan untuk meningkatkan pertumbuhan dan hasil tanaman umumnya dilakukan dengan memberikan pupuk yang mengandung unsur hara makro, tetapi mengabaikan unsur hara mikro, padahal menurut Robb dan Peirpont (1983) dalam Salisbury dan Ross (1995), sebagian besar unsur hara mikro adalah esensial karena berperan mengaktifkan enzim, yaitu zat yang berperan penting untuk berlangsungnya proses metabolisme dalam tubuh tanaman (Dwidjoseputro, 2005).

Salah satu unsur hara mikro esensial bagi tanaman adalah seng ( $\mathrm{Zn})$. $\mathrm{Zn}$ merupakan unsur yang diperlukan oleh tanaman, hewan, dan manusia dalam jumlah sedikit, tetapi mutlak harus ada. Tanaman dan hewan yang mengalami kekurangan $\mathrm{Zn}$ akan mengalami cekaman fisiologis yang disebabkan oleh tidak berfungsinya beberapa sistem enzim dan fungsi metabolik (Indradewa, 2007), karena Zn berperan penting sebagai kofaktor dan mengaktifkan berbagai enzim (Dwidjoseputro, 2005; Sudarmi, 2013). Zn diperlukan untuk pembentukan auksin (Salisbury dan Ross, 1995), suatu zat yang berperan dalam pengembangan dan diferensiasi sel pada daerah meristem, pembentukan buah, serta mencegah gugurnya bunga dan buah (Dwidjoseputro, 2005), sebagai katalisator dalam proses metabolisme karbohidrat, baik fotosintesis maupun perubahan gula menjadi pati, metabolisme protein dan auksin, pembentukan klorofil, polen, dan sistem enzim yang mengatur pertumbuhan, perawatan integritas membran biologis, dan ketahanan terhadap infeksi atau patogen tertentu (Alloway, 2008; Indradewa, 2007).

Kekurangan $\mathrm{Zn}$ merupakan masalah yang paling sering ditemui dan meluas dibandingkan dengan unsur hara mikro lain (Indradewa, 2007). Kekurangan $\mathrm{Zn}$ secara fisiologis menyebabkan pertumbuhan tanaman menjadi lambat akibat melemahnya sintesis hormon pertumbuhan, gangguan metabolisme $\mathrm{N}$, kadar RNA menurun, serta menurunnya sintesis pati pada tanaman (Alloway, 2008), daun mengecil dan pucuk membentuk roset serta timbul warna-warna tidak normal pada tanaman (Sudarmi, 2013).

Selain ketersediaan unsur hara, pertumbuhan dan hasil tanaman dipengaruhi 
oleh jarak tanam. Jarak tanam yang tepat diperlukan untuk mengatur populasi dan tersedianya faktor-faktor lingkungan yang mempengaruhi pertumbuhan dan hasil tanaman. Hal ini sejalan dengan pendapat Jumin (2005) yang mengemukakan bahwa pengaturan populasi dan jarak tanam mempengaruhi tersedianya faktor-faktor tumbuh. Jarak tanam dapat mempengaruhi populasi tanaman dan efisiensi penggunaan cahaya matahari serta kompetisi antara tanaman dalam memperoleh air dan unsur hara sehingga akan mempengaruhi hasil tanaman.

Menurut Cahyono (2003), pengaturan jarak tanam mendukung pertumbuhan dan hasil tanaman, berpengaruh terhadap iklim mikro di sekitar tanaman dan penerimaan cahaya matahari. Jarak tanam rapat menyebabkan kelembapan udara yang tinggi di sekitar tanaman, sehingga tidak menguntungkan untuk pertumbuhan tanaman karena tanaman mudah terserang penyakit. Sarpian (2003) menambahkan, jarak tanam yang tidak tepat akan menimbulkan pengaruh negatif dan beberapa kerugian. Jarak tanam terlalu rapat menyebabkan pertumbuhan dahan terhambat sehingga mahkota tanaman tidak rimbun dan cahaya matahari tidak dapat diterima dengan baik oleh tanaman, sehingga proses fotosintesis terhambat dan produksi buah tidak maksimal, meskipun tanaman diberikan pupuk yang cukup mengandung fosfor.

Tujuan penelitian adalah untuk mengetahui: (1) dosis pupuk $\mathrm{Zn}$ dan jarak tanam secara tunggal yang memberikan pertumbuhan dan hasil terbaik tanaman tomat; 2) interaksi antara dosis pupuk $\mathrm{Zn}$ dan jarak tanam terhadap pertumbuhan dan hasil tanaman tomat; 3) hubungan (korelasi) antara dua variabel yang diamati.

\section{METODE PENELITIAN}

\section{Tempat dan Waktu}

Penelitian dilaksanakan selama kurang lebih empat bulan (Juli - Oktober 2018), di Desa Teluk Dalam, Kelurahan Mulawarman,
Kecamatan Tenggarong Seberang, Kabupaten Kutai Kartanegara, Kalimantan Timur.

\section{Bahan dan Alat}

Bahan-bahan yang dipakai dalam penelitian terdiri atas benih tomat varietas Permata, pupuk $\mathrm{ZnSO}_{4}$, pupuk NPK (15:15:15), pupuk SP-36, kapur dolomit, Curacron 500 EC, dan Agrept 25 WP. Alatalat yang dipakai terdiri atas cangkul, meteran, arit, parang, gunting , tali rafia, ember, papan plang perlakuan, kalkulator, ceratester, gunting, ajir, gelas ukur, hand sprayer, kamera, alat tulis-menulis, polybag, timbangan analitik dan alat dokumentasi.

\section{Rancangan Penelitian}

Penelitian merupakan percobaan faktorial 4x3 disusun dalam Rancangan Acak Kelompok (RAK) dan setiap perlakuan diulang sebanyak tiga kali. Faktor pertama adalah pupuk $\mathrm{Zn}$, terdiri atas empat taraf, yaitu 0,00 (kontrol); 2,25 $\mathrm{g}_{\text {petak }}{ }^{-1}$ setara dengan 3,00 $\mathrm{kg} \mathrm{Zn} \mathrm{ha}{ }^{-1}$; 4,50 $\mathrm{g}$ petak $^{-1}$ setara dengan $6,00 \mathrm{~kg} \mathrm{Zn} \mathrm{ha}^{-1} ; 6,75 \mathrm{~g}$ petak $^{-1}$ setara dengan 9,00 $\mathrm{kg} \mathrm{Zn} \mathrm{ha}^{-1}$. Faktor kedua adalah jarak tanam, terdiri atas tiga taraf, yaitu $50 \mathrm{~cm}$ x $50 \mathrm{~cm} ; 60 \mathrm{~cm}$ x $50 \mathrm{~cm}$; dan $70 \mathrm{~cm}$ x $50 \mathrm{~cm}$.

\section{Pelaksanaan Penelitian}

1. Persemaian dan Persiapan Bibit

Persemaian dibuat pada polybag berukuran $10 \mathrm{~cm} \times 8 \mathrm{~cm}$ yang diisi campuran tanah dan pupuk kandang dengan perbandingan 1:1. Polybag persemaian ditempatkan di dalam tempat persemaian berukuran panjang dan lebar masing-masing $200 \mathrm{~cm}$, tinggi tiang persemaian sebelah Timur 175 $\mathrm{cm}$ dan sebelah Barat $125 \mathrm{~cm}$ dan diberi atap dari plastik transparan. Benih ditanam sedalam $0,50-1,00 \mathrm{~cm}$. Bibit siap dipindahkan setelah berumur 21 hari.

2. Pengolahan Tanah

Lahan penelitian terlebih dahulu dibersihkan dari gulma dan kotoran lain, kemudian dilakukan pengolahan tanah dengan cara dicangkul, setelah itu dibiarkan selama satu minggu, selanjutnya dibuat petak-petak sebanyak 36 petak yang dibagi menjadi tiga kelompok, masing masing 
berukuran $300 \mathrm{~cm}$ x $250 \mathrm{~cm}$ dengan tinggi petak $30 \mathrm{~cm}$. Setiap kelompok terdiri atas 12 petak, jarak antar petak $50 \mathrm{~cm}$ dan jarak antar kelompok $100 \mathrm{~cm}$. Kapur dolomit dengan dosis $750 \mathrm{~g} \mathrm{petak}^{-1}$ diberikan dua minggu sebelum tanam bersamaan dengan saat pengolahan tanah. Pupuk dasar NPK dan SP-36 dengan dosis masing-masing 375 g petak ${ }^{-1}$ setara dengan $500 \mathrm{~kg} \mathrm{ha}^{-1}$ dan $31,50 \mathrm{~g}$ petak $^{-1}$ setara dengan $15 \mathrm{~kg} \mathrm{ha}^{-1}$ diberikan satu kali, yaitu seminggu sebelum tanam pada lahan yang telah diolah.

3. Penanaman

Penanaman dilakukan setelah bibit berumur 21 hari dengan ciri-ciri: tinggi bibit sekitar $10 \mathrm{~cm}$ dan mempunyai 4-5 helai daun. Bibit yang telah dipilih (sehat dan seragam) dipindahkan ke petak percobaan yang telah disiapkan dengan jarak tanam sesuai perlakuan, yaitu $50 \mathrm{~cm} \mathrm{x}$ $50 \mathrm{~cm} ; 60 \mathrm{~cm}$ x $50 \mathrm{~cm}$; dan $70 \mathrm{~cm} \times 50 \mathrm{~cm}$. Penanaman dilakukan pada sore hari, setelah ditanam, bibit disiram secukupnya.

4. Pemberian Perlakuan

Pupuk $\mathrm{Zn}$ diberikan dalam dua tahap, yaitu $1 / 2$ dari dosis perlakuan diberikan $2 \mathrm{mst}$, sisanya (1/2 dari dosis) diberikan $4 \mathrm{mst}$. Pupuk diberikan dalam bentuk larutan dengan cara disiramkan ke tanaman dengan dosis $50 \mathrm{~mL}$ per tanaman.

5. Pemeliharaan

Pemeliharaan tanaman meliputi: penyiraman; penyulaman terhadap tanaman yang rusak, mati atau kurang baik pertumbuhannya, dilakukan sebelum tanaman berumur 2 minggu; pemasangan ajir dilakukan pada umur 2 minggu setelah tanam (mst); penyiangan dan penggemburan dilakukan pada saat tanaman berumur $2 \mathrm{mst}$; pemangkasan terhadap tunas-tunas yang tumbuh di sela-sela cabang, dilakukan pada saat tanaman berumur 20 hari setelah tanam (hst); dan pengendalian hama dan penyakit.
Buah tomat dipanen dengan kriteria buah berwarna orange sampai kemerahan. Panen dilakukan pada pagi atau sore hari dengan cara memutar buah tomat secara hati-hati sampai buah terlepas dari tangkainya. Panen dilakukan dengan interval waktu tiga hari sekali.

\section{Pengumpulan Data}

Variabel yang diamati dalam penelitian terdiri atas: (1) tinggi tanaman saat tanaman berbunga dan saat panen pertama; (2) umur tanaman saat berbunga $80 \%$ dan saat panen pertama; (3) jumlah cabang per tanaman; (4) jumlah buah per tanaman; (5) berat segar buah per tanaman: (6) frekuensi panen; dan (7) berat segar buah per hektar.

\section{Analisis Data}

Data hasil penelitian dianalisis menggunakan sidik ragam, apabila pengaruh perlakuan menunjukkan berbeda nyata, maka untuk membandingkan antara rata-rata dua perlakuan, dilanjutkan dengan Uji Beda Nyata Terkecil (BNT) pada taraf 5\%. Analisis korelasi dipakai untuk mengetahui hubungan antara berat segar buah per hektar dengan variabel-variabel lain.

\section{HASIL DAN PEMBAHASAN}

\section{Pengaruh Pemberian Pupuk Zn}

Hasil sidik ragam menunjukkan bahwa pengaruh pemberian pupuk $\mathrm{Zn}$ berbeda nyata terhadap rata-rata tinggi tanaman, umur tanaman saat panen pertama, jumlah buah per tanaman, berat segar buah per tanaman, frekuensi panen, dan berat segar buah per hektar, tetapi berbeda tidak nyata terhadap tinggi tanaman saat berbunga, umur tanaman saat berbunga $80 \%$, dan jumlah cabang per tanaman. Rekapitulasi hasil analisis data pertumbuhan dan hasil tanaman tomat pada pemberian pupuk $\mathrm{Zn}$ disajikan pada Tabel 1 berikut.

6. Panen 
Tabel 1. Rekapitulasi Hasil Analisis Data Pertumbuhan dan Hasil Tanaman Tomat pada Pemberian Pupuk Zn

\begin{tabular}{|c|c|c|c|c|c|c|c|c|c|}
\hline \multirow{2}{*}{$\begin{array}{c}\text { Dosis } \\
\text { Pupuk Zn } \\
(\mathrm{P}) \\
\left(\mathrm{kg} \mathrm{ha}^{-1}\right)\end{array}$} & \multicolumn{2}{|c|}{$\begin{array}{c}\text { Tinggi Tanaman }(\mathrm{cm}) \\
\text { Saat }\end{array}$} & \multicolumn{2}{|c|}{$\begin{array}{l}\text { Umur Tanaman (hst) } \\
\text { Saat } \\
\end{array}$} & \multirow{2}{*}{$\begin{array}{c}\text { Jumlah } \\
\text { Cabang } \\
\text { per } \\
\text { Tanaman } \\
\text { (cabang) }\end{array}$} & \multirow{2}{*}{$\begin{array}{l}\text { Jumlah } \\
\text { Buah per } \\
\text { Tanaman } \\
\text { (buah) }\end{array}$} & \multirow{2}{*}{$\begin{array}{c}\text { Berat } \\
\text { Segar } \\
\text { Buah per } \\
\text { Tanaman } \\
(\mathrm{g})\end{array}$} & \multirow{2}{*}{$\begin{array}{c}\text { Frekuensi } \\
\text { Panen } \\
\text { (kali) }\end{array}$} & \multirow{2}{*}{$\begin{array}{c}\text { Berat Segar } \\
\text { Buah per } \\
\text { Hektar } \\
\left(\mathrm{Mg} \mathrm{ha}^{-1}\right)\end{array}$} \\
\hline & Berbunga & $\begin{array}{c}\text { Panen } \\
\text { Pertama }\end{array}$ & $\begin{array}{l}\text { Berbunga } \\
80 \%\end{array}$ & $\begin{array}{c}\text { Panen } \\
\text { Pertama }\end{array}$ & & & & & \\
\hline $0,00\left(\mathrm{p}_{0}\right)$ & 62,02 & $101,92^{\mathrm{a}}$ & 32,44 & $67,22^{a b}$ & 6,95 & $22,36^{b}$ & $5.084,09^{b}$ & $3,67^{b}$ & $21,47^{b}$ \\
\hline $3,00\left(\mathrm{p}_{1}\right)$ & 62,44 & $107,07^{\mathrm{ab}}$ & 32,33 & $67,33^{\mathrm{a}}$ & 6,73 & $22,65^{\mathrm{b}}$ & $5.401,71^{\mathrm{ab}}$ & $4,11^{\mathrm{ab}}$ & $22,74^{\mathrm{ab}}$ \\
\hline $6,00\left(\mathrm{p}_{2}\right)$ & 67,08 & $108,16^{\mathrm{ab}}$ & 32,11 & $66,89^{b c}$ & 7,17 & $24,94^{\mathrm{a}}$ & $5.964,60^{\mathrm{a}}$ & $4,33^{\mathrm{ab}}$ & $25,16^{\mathrm{a}}$ \\
\hline $9,00\left(\mathrm{p}_{3}\right)$ & 64,10 & $112,42^{\mathrm{a}}$ & 32,11 & $66,67^{\mathrm{c}}$ & 7,06 & $25,68^{\mathrm{a}}$ & $5.923,38^{\mathrm{a}}$ & $4,78^{\mathrm{a}}$ & $24,96^{\mathrm{a}}$ \\
\hline BNT5\% & - & 7,93 & - & 0,41 & - & 2,19 & $1.139,47$ & 0,71 & 0,46 \\
\hline
\end{tabular}

Keterangan: Angka rata-rata yang diikuti oleh huruf yang sama pada kolom menunjukkan berbeda tidak nyata dengan uji BNT pada taraf 5\%.

Hasil sidik ragam menunjukkan bahwa pengaruh pupuk $\mathrm{Zn}$ tidak nyata perbedaannya terhadap rata-rata tinggi tanaman saat berbunga, diduga hal ini berhubungan dengan tipe pertumbuhan tanaman tomat varietas Permata yang termasuk determinate (tertentu), yaitu saat tanaman memasuki fase berbunga, pertumbuhan vegetatif akan berhenti. Hal ini sesuai dengan pendapat Taiz and Zeiger (1998), bahwa pembungaan pada tanaman dengan tipe pertumbuhan determinate terjadi setelah tanaman mencapai jumlah daun tetap dan pertumbuhan vegetatifnya berhenti.

Selain itu, hasil analisis kimia tanah menunjukkan kadar $\mathrm{N}$ total dalam tanah $(0,56 \%)$ termasuk tinggi, sehingga mempengaruhi ketersediaan Zn. Menurut Indradewa (2007), ketersediaan seng (Zn) dipengaruhi oleh $\mathrm{N}$, diantaranya melalui pembentukan kompleks seng-protein karena $\mathrm{Zn}$ meningkatkan pembentukan protein yang menyebabkan $\mathrm{Zn}$ ditahan di akar. Kekurangan $\mathrm{Zn}$ secara fisiologis menyebabkan pertumbuhan tanaman menjadi lambat akibat melemahnya sintesis hormon pertumbuhan Alloway (2008), karena Zn diperlukan untuk pembentukan auksin (Salisbury dan Ross, 1995), zat yang mempunyai sifat khas, yaitu mendorong pembelahan dan perpanjangan sel pucuk (Taiz dan Zeiger, 1998), gangguan metabolisme $\mathrm{N}$, kadar RNA menurun, serta menurunnya sintesis pati pada tanaman Alloway (2008).

Pengaruh pemberian pupuk $\mathrm{Zn}$ berbeda tidak nyata terhadap umur tanaman saat berbunga $80 \%$ dan jumlah cabang per tanaman diduga berhubungan dengan sifat genetik tanaman. Sifat genetik tanaman berpengaruh terhadap ciri dan sifat tanaman, yaitu bentuk tubuh, warna bunga, rasa buah, serta menentukan kemampuan metabolisme, sehingga mempengaruhi pertumbuhan dan perkembangan tanaman. Oleh karena itu, meskipun diberikan pupuk $\mathrm{Zn}$, kadar $\mathrm{Zn}$ belum mampu memacu aktivitas enzin-enzim yang berperan dalam proses metabolisme tanaman sehingga sifat-sifat genetik potensialnya tidak dapat diekspresikan untuk mempersingkat umur tanaman saat berbunga dan meningkatkan jumlah cabang. Heddy (1996) menjelaskan bahwa umur tanaman pada tanaman tertentu sudah ditentukan oleh sifat genetik tanaman tersebut.

Hasil sidik ragam terhadap rata-rata tinggi tanaman saat panen pertama menunjukkan bahwa pengaruh pupuk $\mathrm{Zn}$ berbeda nyata. Hal ini diduga berhubungan dengan ketersediaan $\mathrm{Zn}$ yang dibutuhkan oleh tanaman untuk pembentukan klorofil dan enzim, sehingga proses metabolisme, khususnya fotosintesis, menjadi meningkat. Fotosintat yang cukup akan meningkatkan laju pembelahan, pemanjangan, dan diferensiasi sel pada titik tumbuh tanaman, dengan demikian pada akhirnya meningkatkan pertumbuhan tanaman. Harjadi (2001) menjelaskan bahwa pada fase vegetatif, sebagian besar karbohidrat dipakai oleh tanaman untuk pembelahan, pemanjangan, dan diferensiasi sel. Karbohidrat yang tersedia dalam jumlah cukup menyebabkan pertumbuhan dan perkembangan akar, batang, dan daun akan meningkat.

Berdasarkan hasil uji BNT pada taraf $5 \%$, dosis pupuk $9,00 \mathrm{~kg} \mathrm{Zn} \mathrm{ha}^{-1}$ berbeda nyata dengan perlakuan $0,00 \mathrm{~kg} \mathrm{Zn} \mathrm{ha}^{-1}$ (kontrol), tetapi berbeda tidak nyata dengan perlakuan 


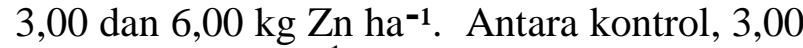
dan $6,00 \mathrm{~kg} \mathrm{Zn} \mathrm{ha}^{-1}$ berbeda tidak nyata. Ratarata tinggi tanaman saat panen pertama tertinggi diperoleh pada perlakuan dosis pupuk 9,00 kg Zn ha-1, diikuti oleh 6,00 dan 3,00 kg $\mathrm{Zn} \mathrm{ha}{ }^{-1}$, yaitu berturut-turut 112,$42 ; 108,16$; dan $107,07 \mathrm{~cm}$, dan rata-rata paling rendah diperoleh pada kontrol $\left(0,00 \mathrm{~kg} \mathrm{Zn} \mathrm{ha}{ }^{-1}\right)$, yaitu $101,92 \mathrm{~cm}$. Hal ini disebabkan perlakuan pupuk $\mathrm{Zn}$ dengan dosis tertinggi $(9,00 \mathrm{~kg} \mathrm{Zn}$ $\mathrm{ha}^{-1}$ ) yang dipakai dapat memenuhi ketersediaan $\mathrm{Zn}$ secara cukup, ditambah dengan ketersediaan $\mathrm{N}$ total dalam tanah sebesar $0,59 \%$ (tergolong tinggi), sehingga memacu proses fotosintesis, dengan demikian meningkatkan cadangan makanan yang selanjutnya dipakai dalam proses pertumbuhan dan perkembangan tanaman. Menurut Sutedjo (2006), Zn mampu mengaktifkan enzim-enzim potensial yang berperan penting dalam proses metabolisme karbohidrat, protein, dan lemak yang sangat penting dalam proses pembelahan dan perkembangan sel-sel pada jaringan meristem tanaman

Pengaruh pupuk Zn terhadap rata-rata umur tanaman saat panen pertama berbeda nyata, hal ini diduga berkaitan dengan peran Zn sebagai kofaktor dapat memacu aktivitas enzim-enzim yang berperan dalam proses metabolisme tanaman. Enzim akan mempercepat reaksi terang di dalam kloroplas untuk mereduksi energi matahari dengan bantuan $\mathrm{CO}_{2}$ dan $\mathrm{H}_{2} \mathrm{O}$ menjadi ATP dan NADPH. Selanjutnya, pada reaksi gelap, ATP dan NADPH digunakan untuk mengubah karbondioksida menjadi karbohidrat berupa glukosa yang dipakai tanaman sebagai sumber energi. Selain itu, $\mathrm{Zn}$ terlibat langsung dalam pembentukan klorofil dan mencegah perusakan klorofil yang berperan dalam penyerapan cahaya matahari untuk menghasilkan energi. Energi tersebut direduksi menjadi energi kimia yang dipakai oleh tanaman dalam proses pertumbuhan dan perkembangan. Hal ini sesuai dengan pendapat Sudiarso (2017) yang menyatakan bahwa Zn berperan penting sebagai aktivator enzim, pembentukan klorofil, dan berbagai macam aktivator proses-proses biokimia di dalam tanaman.

Hasil uji BNT 5\% terhadap rata-rata umur tanaman saat panen pertama menunjukkan bahwa perlakuan dosis pupuk 9,00 $\mathrm{kg} \mathrm{Zn} \mathrm{ha}{ }^{-1}$ berbeda nyata dengan perlakuan 3,00 $\mathrm{kg} \mathrm{Zn} \mathrm{ha}^{-1}$ dan 0,00 $\mathrm{kg} \mathrm{Zn} \mathrm{ha}^{-1}$ atau kontrol, tetapi berbeda tidak nyata dengan $6,00 \mathrm{~kg} \mathrm{Zn} \mathrm{ha}{ }^{-1}$. Kontrol berbeda tidak nyata dengan $3,00 \mathrm{~kg} \mathrm{Zn} \mathrm{ha}^{-1}$, tetapi berbeda nyata dengan $6,00 \mathrm{~kg} \mathrm{Zn} \mathrm{ha}^{-1}$, antara perlakuan 3,00 dan 6,00 kg Zn ha-1 berbeda tidak nyata. Ratarata umur tanaman saat panen pertama terpendek diperoleh pada perlakuan $9,00 \mathrm{~kg} \mathrm{Zn}$ $\mathrm{ha}^{-1}$, diikuti berturut-turut oleh 6,$00 ; 0,00$; dan 3,00 kg Zn ha ${ }^{-1}$, yaitu 66,67; 66,89; 67,22; dan 67,33 hst. Umur tanaman saat panen pertama cenderung semakin pendek seiring dengan meningkatnya dosis pupuk $\mathrm{Zn}$, hal ini menunjukkan bahwa ketersediaan $\mathrm{Zn}$ secara cukup akan meningkatkan pembentukan klorofil, serta memacu aktivitas enzim dan proses metabolisme karbohidrat, protein, dan auksin (Indradewa, 2007). Klorofil dan enzim berperan dalam proses metabolisme, khususnya fotosintesis, yang menghasilkan cadangan makanan yang disimpan dalam buah. Tanaman akan membentuk bunga, buah dan biji apabila sudah cukup besar, cukup umur, dan cukup cadangan makanan. Sedangkan auksin berperan dalam pengembangan dan diferensiasi sel, pembentukan buah, dan mencegah gugurnya bunga dan buah (Dwidjoseputro, 2005).

Pengaruh pupuk $\mathrm{Zn}$ terhadap rata-rata jumlah buah per tanaman dan frekuensi panen berbeda nyata. Hal ini diduga berkaitan dengan peran $\mathrm{Zn}$ dalam pembentukan klorofil, sebagai katalisator dan mengaktifkan enzimenzim yang memacu proses metabolisme karbohidrat, khususnya fotosintesis, sehingga tanaman mampu menghasilkan cukup banyak karbohidrat untuk dipakai dalam pembentukan organ reproduktif (bunga, buah, dan biji) sekaligus organ penyimpan cadangan makanan (buah dan biji). Disamping itu, $\mathrm{Zn}$ berperan dalam metabolisme auksin yang merupakan senyawa yang berperan mencegah gugurnya 
daun dan buah. Harjadi (2001) menjelaskan bahwa pada fase reproduktif, tanaman menyimpan sebagian besar karbohidrat.

Hasil uji BNT 5\% terhadap rata-rata jumlah buah per tanaman menunjukkan bahwa antara perlakuan 6,00 dan $9,00 \mathrm{~kg} \mathrm{Zn} \mathrm{ha}^{-1}$ berbeda tidak nyata, keduanya berbeda nyata dengan 0,00 dan 3,00 $\mathrm{kg} \mathrm{Zn} \mathrm{ha}^{-1}$, antara 0,00 dan 3,00 kg Zn ha ${ }^{-1}$ berbeda tidak nyata. Ratarata jumlah buah per tanaman terbanyak diperoleh pada perlakuan 9,00 kg Zn ha-1, diikuti oleh 6,00; 3,00; dan 0,00 kg Zn ha ${ }^{-1}$, yaitu berturut-turut 25,$68 ; 24,94 ; 22,65$; dan 22,36 buah per tanaman.

Hasil uji BNT 5\% terhadap rata-rata frekuensi panen menunjukkan bahwa antara perlakuan 3,00; 6,00; dan 9,00 $\mathrm{kg} \mathrm{Zn} \mathrm{ha}^{-1}$ berbeda tidak nyata, hanya perlakuan $9,00 \mathrm{~kg}$ $\mathrm{Zn} \mathrm{ha}{ }^{-1}$ yang berbeda nyata dengan kontrol $\left(0,00 \mathrm{~kg} \mathrm{Zn} \mathrm{ha}{ }^{-1}\right)$. Rata-rata frekuensi panen terbanyak ditunjukkan oleh perlakuan $9,00 \mathrm{~kg}$ $\mathrm{Zn} \mathrm{ha}^{-1}$, yaitu 4,78 kali, diikuti berturut-turut oleh perlakuan 6,00; 3,00; dan 0,00 kg Zn ha ${ }^{-1}$, dengan frekuensi panen masing-masing 4,33; 4,11; dan 3,67 kali. Perlakuan dengan dosis pupuk Zn tertinggi yang dicoba $\left(9,00 \mathrm{~kg} \mathrm{ha}^{-1}\right)$ memberikan rata-rata jumlah buah per tanaman dan frekuensi panen terbanyak menunjukkan bahwa semakin tinggi dosis pupuk $\mathrm{Zn}$ yang diberikan sampai dosis tertinggi yang dipakai $\left(9,00 \mathrm{~kg} \mathrm{Zn} \mathrm{ha}^{-1}\right)$ pada penelitian ini, tanaman akan mendapatkan suplai $\mathrm{Zn}$ secara cukup untuk berlangsungnya berbagai proses metabolisme dalam tubuhnya, sehingga pertumbuhan dan hasil tanaman akan meningkat.

Hasil sidik ragam menunjukkan bahwa pengaruh pupuk $\mathrm{Zn}$ terhadap rata-rata berat segar buah per tanaman dan berat segar buah per hektar berbeda nyata. Hal ini diduga selain disebabkan oleh ketersediaan $\mathrm{Zn}$ yang berperan dalam pembentukan klorofil, metabolisme karbohidrat, protein dan auksin, serta sebagai katalisator berbagai enzim, juga tersedianya $\mathrm{N}$ total dalam tanah $(0,56 \%)$ tergolong tinggi, sehingga sintesis asam amino dan protein, pertumbuhan daun dan proses metabolisme, khususnya fotosintesis, menjadi meningkat. Nitrogen merupakan unsur utama dalam sintesis protein yang merupakan penyusun protoplasma dan klorofil. Klorofil bertanggung jawab terhadap konversi energi matahari menjadi energi kimia yang dipakai dalam proses fotosintesis untuk menghasilkan fotosintat. Soepardi (1983), mengemukakan bahwa nitrogen merupakan unsur utama penyusun protein yang berfungsi sebagai pembangun sel, seperti membran sel yang berfungsi untuk membawa materi melintasi membran sel, protein pada asam nukleat yang membentuk basa nitrogen DNA dan RNA, klorofil yang berperan penting dalam proses fotosintesis, dan protein pada protoplasma yang memperlancar proses metabolisme bagi pertumbuhan vegetatif tanaman, sehingga tercapai pertumbuhan yang baik yang pada akhirnya menyebabkan bahan kering tanaman menjadi meningkat. Tersedianya unsur hara $\mathrm{N}$ secara cukup, ditambah ketersediaan unsur mikro Zn yang berperan penting dalam kerja enzim-enzim untuk meningkatkan laju proses biokimia dalam tanaman pada akhirnya berpengaruh dalam peningkatan berat segar buah.

Hasil penelitian menunjukkan bahwa peningkatan berat segar buah seiring dengan peningkatan dosis pupuk $\mathrm{Zn}$ dari 0,00 sampai dengan $6,00 \mathrm{~kg} \mathrm{ha}^{-1}$, tetapi menurun pada dosis 9,00 kg Zn ha ${ }^{-1}$. Perlakuan dosis pupuk 6,00 $\mathrm{kg} \mathrm{Zn} \mathrm{ha}{ }^{-1}$ menghasilkan rata-rata berat segar buah per tanaman dan berat segar buah per hektar tertinggi, yaitu 5.964,60 g dan 25,16 $\mathrm{Mg} \mathrm{ha}^{-1}$; diikuti oleh perlakuan pupuk $\mathrm{Zn}$ dengan dosis 9,00; 3,00; dan 0,00 $\mathrm{kg} \mathrm{Zn} \mathrm{ha}^{-1}$ dengan rata-rata berat segar buah per tanaman berturut-turut 5.923,38; 5.401,71; dan 5.084,09 $\mathrm{g}$ dan berat segar buah per hektar berturut-turut 24,96; 22,74; dan 21,47 $\mathrm{Mg} \mathrm{ha}^{-1}$. Hal ini menunjukkan bahwa pada dosis pupuk $\mathrm{Zn} 6,00$ $\mathrm{kg} \mathrm{ha}^{-1}$ merupakan dosis terbaik dan mampu menyediakan Zn secara cukup untuk memacu kerja enzim-enzim yang berperan dalam sintesis karbohidrat, protein, dan lemak yang diperlukan untuk pertumbuhan dan hasil tanaman. Menurut Sudiarso (2017), Zn merupakan unsur hara mikro esensial yang 
dibutuhkan tanaman untuk merangsang pertumbuhan vegetatif dan pertumbuhan biji maupun buah. Armaini, dkk (2007) menambahkan bahwa berat buah dipengaruhi oleh ketersediaan unsur hara makro $(\mathrm{N}, \mathrm{P}, \mathrm{K}$, $\mathrm{Ca}, \mathrm{Mg}$, dan $\mathrm{S})$ dan unsur hara mikro $(\mathrm{Cu}, \mathrm{Zn}$, $\mathrm{Fe}, \mathrm{B}, \mathrm{Mo}, \mathrm{Mn}, \mathrm{Cl}$ ) yang sangat dibutuhkan untuk berlangsungnya proses fisiologis tanaman.

Berat segar buah meningkat seiring dengan meningkatnya dosis pupuk $\mathrm{Zn}$ sampai $6,00 \mathrm{~kg} \mathrm{Zn} \mathrm{ha}^{-1}$, kemudian menurun pada 9,00 $\mathrm{kg} \mathrm{ha}{ }^{-1}$ walaupun perbedaannya tidak nyata, karena dosis $0,00 \mathrm{~kg} \mathrm{Zn}$ ha $^{-1}$ merupakan daerah kahat $\mathrm{Zn}$, sehingga pemberian pupuk $\mathrm{Zn}$ akan meningkatkan kadar $\mathrm{Zn}$ dalam tanaman sampai dosis $6,00 \mathrm{~kg} \mathrm{Zn} \mathrm{ha}{ }^{-1}$ yang merupakan daerah kecukupan, sedangkan 9,00 $\mathrm{kg} \mathrm{Zn} \mathrm{ha}{ }^{-1}$ merupakan dosis yang melebihi dosis optimum dan dapat menyebabkan keracunan dan penurunan pertumbuhan tanaman sebagaimana dikemukakan oleh Salisbury dan Ross (1995), pada daerah kahat (deficient zone) unsur hara, pertumbuhan tanaman naik sangat tajam bila diberikan unsur hara lebih banyak, sehingga konsentrasinya dalam tanaman meningkat, kenaikan konsentrasi unsur hara akan meningkatkan pertumbuhan tanaman sampai daerah berkecukupan (adequate zone), peningkatan konsentrasi unsur hara lanjut akan menyebabkan keracunan dan menurunnya pertumbuhan (toxic zone).

\section{Pengaruh Jarak Tanam}

Hasil sidik ragam menunjukkan bahwa pengaruh jarak tanam berbeda nyata terhadap semua variabel yang diamati (tinggi tanaman saat berbunga dan saat panen pertama, umur tanaman saat berbunga $80 \%$ dan saat panen pertama, jumlah cabang per tanaman, jumlah buah per tanaman, berat segar buah per tanaman, frekuensi panen, dan berat segar buah per hektar). Rekapitulasi hasil analisis data pertumbuhan dan hasil tanaman tomat pada jarak tanam yang berbeda disajikan pada Tabel 2 di bawah ini.

Tabel 2. Rekapitulasi Hasil Analisis Data Pertumbuhan dan Hasil Tanaman Tomat pada Jarak Tanam yang Berbeda

\begin{tabular}{|c|c|c|c|c|c|c|c|c|c|}
\hline \multirow{2}{*}{$\begin{array}{c}\text { Jarak } \\
\operatorname{Tanam}(\mathrm{J}) \\
(\mathrm{cm} \times \mathrm{cm})\end{array}$} & \multicolumn{2}{|c|}{$\begin{array}{c}\text { Tinggi Tanaman }(\mathrm{cm}) \\
\text { Saat }\end{array}$} & \multicolumn{2}{|c|}{$\begin{array}{l}\text { Umur Tanaman (hst) } \\
\text { Saat }\end{array}$} & \multirow{2}{*}{$\begin{array}{c}\text { Jumlah } \\
\text { Cabang } \\
\text { per } \\
\text { Tanaman } \\
\text { (cabang) }\end{array}$} & \multirow{2}{*}{$\begin{array}{l}\text { Jumlah } \\
\text { Buah per } \\
\text { Tanaman } \\
\text { (buah) }\end{array}$} & \multirow{2}{*}{$\begin{array}{c}\text { Berat } \\
\text { Segar } \\
\text { Buah per } \\
\text { Tanaman } \\
\text { (g) }\end{array}$} & \multirow{2}{*}{$\begin{array}{c}\text { Frekuensi } \\
\text { Panen } \\
\text { (kali) }\end{array}$} & \multirow{2}{*}{$\begin{array}{c}\text { Berat } \\
\text { Segar } \\
\text { Buah per } \\
\text { Hektar } \\
\left(\mathrm{Mg} \mathrm{ha}^{-1}\right)\end{array}$} \\
\hline & Berbunga & $\begin{array}{c}\text { Panen } \\
\text { Pertama }\end{array}$ & $\begin{array}{l}\text { Berbunga } \\
80 \%\end{array}$ & $\begin{array}{c}\text { Panen } \\
\text { Pertama }\end{array}$ & & & & & \\
\hline $50 \times 50\left(\mathrm{j}_{1}\right)$ & $57,88^{b}$ & $100,69^{b}$ & $34,17^{\mathrm{a}}$ & $67,33^{\mathrm{a}}$ & $6,46^{b}$ & $19,26^{\mathrm{c}}$ & $5.864,41^{\mathrm{c}}$ & $4,25^{\mathrm{a}}$ & $23,46^{b}$ \\
\hline $60 \times 50\left(\mathrm{j}_{2}\right)$ & $62,84^{\mathrm{b}}$ & $108,81^{b}$ & $31,50^{\mathrm{b}}$ & $67,50^{\mathrm{a}}$ & $6,96^{\mathrm{ab}}$ & $23,40^{\mathrm{b}}$ & $4.872,41^{\mathrm{b}}$ & $3,58^{b}$ & $22,11^{\mathrm{ab}}$ \\
\hline $70 \times 50\left(\mathrm{j}_{3}\right)$ & $71,00^{\mathrm{a}}$ & $112,67^{\mathrm{a}}$ & $31,08^{\mathrm{b}}$ & $66,25^{\mathrm{b}}$ & $7,52^{\mathrm{a}}$ & $29,06^{\mathrm{a}}$ & $6.043,51^{\mathrm{a}}$ & $4,83^{\mathrm{a}}$ & $25,18^{\mathrm{a}}$ \\
\hline BNT5\% & 6,74 & 6,86 & 0,42 & 0,36 & 0,69 & 1,90 & 120,78 & 0,62 & 0,40 \\
\hline
\end{tabular}

Pengaruh jarak tanam berbeda nyata terhadap semua variabel pertumbuhan dan hasil yang diamati berkaitan dengan iklim mikro di sekitar tanaman dan kompetisi antar tanaman terhadap penerimaan air, cahaya, unsur hara, dan ruang atau space bagi tanaman. Semakin lebar jarak tanam, iklim mikro di sekitar tanaman menjadi lebih baik dan kompetisi antar tanaman dalam penerimaan cahaya, air, dan unsur hara menjadi berkurang. Jarak tanam yang tepat akan memberikan tanaman ruang tumbuh yang seragam. Cahaya, air, dan unsur hara yang cukup menyebabkan proses fotosintesis dapat berjalan maksimal sehingga menghasilkan karbohidrat dalam jumlah yang cukup untuk meningkatkan laju pertumbuhan dan hasil. Menurut Cahyono, (2000), jarak tanam yang lebar menyebabkan intensitas cahaya dan unsur hara yang diterima oleh individu tanaman semakin banyak, sehingga proses fotosintesis akan meningkat, hal ini akan meningkatkan ketersediaan karbohidrat sebagai sumber karbon dan cadangan makanan bagi tanaman. Sastra (2003), menambahkan bahwa proses fotosintesis akan berlangsung secara sempurna apabila unsur hara, air dan cahaya matahari tersedia secara cukup, selain 
itu, tersedianya unsur hara dan air akan mempengaruhi perkembangan akar dan hasil tanaman.

Hasil penelitian menunjukkan bahwa tinggi tanaman saat berbunga dan saat panen pertama, jumlah cabang per tanaman, jumlah buah per tanaman, frekuensi panen, berat segar buah per tanaman dan berat segar buah per hektar semakin meningkat dengan jarak tanam yang lebih lebar yang dipakai, sedangkan umur tanaman saat berbunga $80 \%$ dan saat panen pertama menjadi lebih pendek.

Jarak tanam yang lebih lebar $(70 \mathrm{~cm}$ x 50 $\mathrm{cm})$ menghasilkan tinggi tanaman yang lebih tinggi, jumlah cabang yang lebih banyak, umur tanaman berbunga dan umur panen yang lebih pendek, jumlah buah dan frekuensi panen lebih banyak, serta berat segar buah yang lebih tinggi dibandingkan jarak tanam yang lebih sempit, yaitu $60 \mathrm{~cm}$ x $50 \mathrm{~cm}$ dan $50 \mathrm{~cm}$ x 50 $\mathrm{cm}$. Hal ini disebabkan pada jarak tanam yang lebih lebar, populasi tanaman lebih sedikit, sehingga kurang terjadi kompetisi antara individu tanaman yang menyebabkan penerimaan cahaya, air, karbondioksida, dan unsur hara oleh tanaman, serta iklim mikro yang lebih baik, dengan demikian proses metabolisme, khususnya fotosintesis, dapat berjalan secara maksimal. Proses fotosintesis yang maksimal akan menghasilkan karbohidrat yang cukup untuk dipakai dalam proses pertumbuhan pada fase vegetatif dan disimpan dalam buah dan biji pada fase reproduktif tanaman, sehingga diperoleh pertumbuhan dan hasil tanaman yang tinggi. Hal ini sesuai dengan pendapat Hidayat (2008) dan Jumin (2005) yang mengemukakan bahwa jarak tanam akan mempengaruhi kepadatan dan efisiensi penggunaan cahaya, persaingan diantara tanaman dalam penggunaan air dan unsur hara sehingga akan mempengaruhi hasil tanaman. Pada kerapatan rendah, tanaman kurang berkompetisi dengan tanaman lain, sehingga penampilan individu tanaman lebih baik. Sebaliknya pada kerapatan tinggi, tingkat kompetisi diantara tanaman terhadap cahaya, air dan unsur hara semakin ketat sehingga tanaman dapat terhambat pertumbuhannya.

Gardner, et al, (1991) menambahkan bahwa jarak tanam yang lebar akan memberikan hasil fotosintesis yang optimal yang akan digunakan untuk pertumbuhan dan pembentukan buah. Hal ini didukung oleh hasil penelitian Maddonny (2013) yang menunjukkan bahwa jarak tanam yang lebar mampu meningkatkan produksi tanaman per hektar yang lebih tinggi. Harjadi (2001) menambahkan bahwa pada fase vegetatif, sebagian besar karbohidrat dipakai oleh tanaman untuk pembelahan, pemanjangan, dan diferensiasi sel. Karbohidrat yang tersedia dalam jumlah cukup menyebabkan pertumbuhan dan perkembangan akar, batang, dan daun akan meningkat, sedangkan pada fase reproduktif, tanaman menyimpan sebagian besar karbohidrat.

Sebaliknya, semakin rapat jarak tanam, populasi tanaman semakin tinggi, mengakibatkan terjadi kompetisi antara individu tanaman dalam mendapatkan cahaya, air, dan unsur hara. Selain itu, pada kerapatan tanaman yang tinggi, tajuk tanaman saling bersinggungan, sehingga menyebabkan bunga dan buah gugur. Menurut Gardner, et al (1991), pada kerapatan populasi yang tinggi, tanaman akan saling melindungi sehingga cahaya dan difusi karbondioksida ke dalam kanopi tidak merata, hal ini berakibat menurunnya hasil fotosintesis yang digunakan untuk pertumbuhan dan pembentukan buah.

\section{Interaksi antara Pupuk Zn dengan Jarak Tanam}

Hasil sidik ragam menunjukkan bahwa pengaruh interaksi antara pupuk $\mathrm{Zn}$ dengan jarak tanam berbeda tidak nyata pada semua variabel pertumbuhan dan hasil tanaman tomat. Rekapitulasi hasil analisis data pertumbuhan dan hasil tanaman tomat pada pemberian pupuk $\mathrm{Zn}$ dan jarak tanam berbeda disajikan pada Tabel 3 berikut. 
Tabel 3. Rekapitulasi Hasil Analisis Data Pertumbuhan dan Hasil Tanaman Tomat pada Pemberian Pupuk Zn dan Jarak Tanam yang Berbeda

\begin{tabular}{|c|c|c|c|c|c|c|c|c|c|}
\hline \multirow{2}{*}{$\begin{array}{l}\text { Interaksi } \\
(\mathrm{P} \times \mathrm{J})\end{array}$} & \multicolumn{2}{|c|}{$\begin{array}{c}\text { Tinggi Tanaman }(\mathrm{cm}) \\
\text { Saat } \\
\end{array}$} & \multicolumn{2}{|c|}{$\begin{array}{l}\text { Umur Tanaman (hst) } \\
\text { Saat }\end{array}$} & \multirow{2}{*}{$\begin{array}{l}\text { Jumlah } \\
\text { Cabang } \\
\text { (cabang) }\end{array}$} & \multirow{2}{*}{$\begin{array}{l}\text { Jumlah } \\
\text { Buah per } \\
\text { Tanaman } \\
\text { (buah) }\end{array}$} & \multirow{2}{*}{$\begin{array}{c}\text { Berat } \\
\text { Segar } \\
\text { Buah per } \\
\text { Tanaman } \\
\quad(g)\end{array}$} & \multirow{2}{*}{$\begin{array}{c}\text { Frekuensi } \\
\text { Panen } \\
\text { (kali) }\end{array}$} & \multirow{2}{*}{$\begin{array}{c}\text { Berat Segar } \\
\text { Buah per } \\
\text { Hektar } \\
\left(\mathrm{Mg} \mathrm{ha}^{-1}\right)\end{array}$} \\
\hline & Berbunga & $\begin{array}{l}\text { Panen } \\
\text { Pertama }\end{array}$ & $\begin{array}{c}\text { Berbunga } \\
80 \%\end{array}$ & $\begin{array}{c}\text { Panen } \\
\text { Pertama }\end{array}$ & & & & & \\
\hline $\mathrm{p}_{0} \times \mathrm{j}_{1}$ & 48,19 & 85,40 & 34,00 & 67,67 & 6,11 & 17,33 & $5.314,58$ & 4,00 & 21,27 \\
\hline $\mathrm{p}_{1} \times \mathrm{j}_{1}$ & 56,01 & 103,56 & 34,00 & 67,67 & 6,61 & 19,61 & $5.959,34$ & 4,33 & 23,84 \\
\hline $\mathrm{p}_{2} \times \mathrm{j}_{1}$ & 66,55 & 105,10 & 34,00 & 67,00 & 6,33 & 20,50 & $6.147,17$ & 4,33 & 24,59 \\
\hline $\mathrm{p}_{3} \times \mathrm{j}_{1}$ & 60,79 & 108,71 & 34,67 & 67,00 & 6,78 & 19,61 & $6.036,55$ & 4,33 & 24,13 \\
\hline $\mathrm{p}_{0} \times \mathrm{j}_{2}$ & 63,46 & 105,32 & 32,00 & 67,67 & 7,42 & 23,08 & $4.605,85$ & 3,00 & 20,92 \\
\hline $\mathrm{p}_{1} \times \mathrm{j}_{2}$ & 62,20 & 105,98 & 31,67 & 67,67 & 6,92 & 22,00 & $4.487,72$ & 3,67 & 20,39 \\
\hline $\mathrm{p}_{2} \times \mathrm{j}_{2}$ & 67,15 & 112,01 & 31,33 & 67,67 & 6,67 & 23,25 & $5.193,01$ & 3,67 & 23,59 \\
\hline $\mathrm{p}_{3} \times \mathrm{j}_{2}$ & 58,54 & 111,91 & 31,00 & 67,00 & 6,83 & 25,25 & $5.203,08$ & 4,00 & 22,22 \\
\hline $\mathrm{p}_{0} \times \mathrm{j}_{3}$ & 74,40 & 115,02 & 31,33 & 66,33 & 7,33 & 26,67 & $5.331,84$ & 4,00 & 23,99 \\
\hline $\mathrm{p}_{1} \times \mathrm{j}_{3}$ & 69,10 & 111,68 & 31,33 & 66,67 & 6,67 & 26,33 & $5.758,06$ & 4,33 & 27,31 \\
\hline $\mathrm{p}_{2} \times \mathrm{j}_{3}$ & 67,54 & 107,36 & 31,00 & 66,00 & 8,50 & 31,08 & $6.553,63$ & 5,00 & 27,31 \\
\hline $\mathrm{p}_{03} \times \mathrm{j}_{3}$ & 72,96 & 116,62 & 30,67 & 66,00 & 7,58 & 32,17 & $6.530,50$ & 6,00 & 27,22 \\
\hline
\end{tabular}

Hasil sidik ragam menunjukkan bahwa pengaruh interaksi antara dosis pupuk $\mathrm{Zn}$ dan jarak tanam berbeda tidak nyata terhadap semua variabel pertumbuhan dan hasil yang diamati. Menurut Gomez dan Gomez (1995), apabila interaksi tidak nyata, artinya pengaruh sederhana suatu faktor sama terhadap semua taraf faktor yang lain dan sama dengan pengaruh utama. Berkaitan dengan perlakuan pupuk $\mathrm{Zn}$ dan jarak tanam, artinya bahwa pengaruh sederhana dosis pupuk $\mathrm{Zn}$ sama terhadap semua taraf jarak tanam, begitu pula sebaliknya, pengaruh sederhana jarak tanam sama terhadap semua taraf dosis pupuk Zn.

Interaksi antara pupuk $\mathrm{Zn}$ dan jarak tanam tidak nyata diduga karena $\mathrm{Zn}$ merupakan unsur hara mikro, yaitu unsur hara yang dibutuhkan tanaman dalam jumlah sedikit, sehingga jarak tanam yang dipakai tidak nyata pengaruhnya terhadap ketersediaan Zn. Begitu pula sebaliknya, jarak tanam yang dipakai belum menyebabkan terjadinya kompetisi antar tanaman terhadap kebutuhan $\mathrm{Zn}$, sehingga pengaruh dosis pupuk $\mathrm{Zn}$ tidak nyata terhadap jarak tanam. Menurut Rosmarkam dan Yuwono (2002), unsur hara mikro merupakan unsur hara esensial bagi tanaman, namun dibutuhkan dalam jumlah sedikit, yaitu <100 ppm (Pendias, 2011). Hasil penelitian Hasanuddin, dkk, (1999) menunjukkan bahwa pengaturan jarak tanam dapat mengurangi persaingan tanaman budidaya dalam mendapatkan air, cahaya, dan unsur hara.

Disamping itu, hal ini diduga berkaitan dengan habitus dan perakaran tanaman tomat yang tidak terlalu lebar dan tajuk yang tidak terlalu rimbun, sehingga kompetisi antar tanaman terhadap penerimaan cahaya, air, dan unsur hara kurang terjadi. Hal ini diperkuat oleh pernyataan Susanto (1994), yang mengemukakan bahwa jarak tanam tidak hanya dipengaruhi oleh habitus tanaman dan luasnya perakaran, tetapi juga oleh faktorfaktor lainnya yang dapat mempengaruhi turunnya produktivitas tanaman yang mendapatkan kerugian bagi petani.

\section{Analisis Korelasi}

Hasil analisis korelasi terhadap variabelvariabel yang diamati ditunjukkan pada Tabel 4. Hasil analisis korelasi menunjukkan bahwa variabel berat segar buah per hektar berkorelasi positif dengan variabel-variabel: tinggi tanaman saat berbunga dan saat panen pertama, jumlah cabang, jumlah buah per tanaman, berat segar buah per tanaman, dan frekuensi panen dengan nilai koefisien korelasi (r) berturut-turut 0,$2895 ; 0,0436 ; 0,2456$; 0,7350; 0,8190; dan 0,6316, tetapi berkorelasi negatif dengan umur tanaman saat berbunga $80 \%$ dan saat panen pertama, yaitu $-0,2552$ dan $-0,3292$. 
Tabel 4. Hasil Analisis Korelasi antara Variabel-Variabel yang Diamati

\begin{tabular}{|c|c|c|c|c|c|c|c|c|c|c|}
\hline $\begin{array}{c}\text { Variabel } \\
\text { yang } \\
\text { Diamati }\end{array}$ & & $\begin{array}{l}\text { Tinggi } \\
\text { Tanaman } \\
\text { Saat } \\
\text { Berbunga } \\
(\mathrm{cm})\end{array}$ & $\begin{array}{c}\text { Tinggi } \\
\text { Tanaman } \\
\text { Saat Panen } \\
\text { Pertama } \\
(\mathrm{cm})\end{array}$ & $\begin{array}{c}\text { Umur } \\
\text { Tanaman } \\
\text { Saat } \\
\text { Berbunga } \\
80 \% \\
\text { (hst) } \\
\end{array}$ & $\begin{array}{c}\text { Umur } \\
\text { Tanaman } \\
\text { Saat Panen } \\
\text { Pertama } \\
\text { (hst) }\end{array}$ & $\begin{array}{c}\text { Jumlah } \\
\text { Cabang } \\
\text { per } \\
\text { Tanaman } \\
\text { (cabang) }\end{array}$ & $\begin{array}{l}\text { Jumlah } \\
\text { Buah per } \\
\text { Tanaman } \\
\text { (buah) }\end{array}$ & $\begin{array}{c}\text { Berat } \\
\text { Segar } \\
\text { Buah per } \\
\text { Tanaman } \\
\text { (g) }\end{array}$ & $\begin{array}{c}\text { Frekuensi } \\
\text { Panen } \\
\text { (kali) }\end{array}$ & $\begin{array}{c}\text { Berat } \\
\text { Segar } \\
\text { Buah per } \\
\text { Hektar } \\
\left(\mathrm{Mg} \mathrm{ha}^{-1}\right)\end{array}$ \\
\hline $\mathrm{Y}_{1}$ & $\begin{array}{l}\mathrm{r} \\
\mathrm{n}\end{array}$ & $\begin{array}{l}1,0000 \\
0,0000\end{array}$ & & & & & & & & \\
\hline $\mathrm{Y}_{2}$ & $\begin{array}{l}\mathrm{r} \\
\mathrm{n}\end{array}$ & $\begin{array}{l}0,6605 \\
0,0001\end{array}$ & $\begin{array}{l}1,0000 \\
0,0000\end{array}$ & & & & & & & \\
\hline $\mathrm{Y}_{3}$ & $\begin{array}{l}\mathrm{r} \\
\mathrm{n}\end{array}$ & $\begin{array}{r}-0,4739 \\
0,0035\end{array}$ & $\begin{array}{r}-0,4893 \\
0,0025\end{array}$ & $\begin{array}{l}1,0000 \\
0,0000\end{array}$ & & & & & & \\
\hline $\mathrm{Y}_{4}$ & $\begin{array}{l}\mathrm{r} \\
\mathrm{n}\end{array}$ & $\begin{array}{r}-0,4725 \\
0,0036\end{array}$ & $\begin{array}{r}-0,4496 \\
0,0059\end{array}$ & $\begin{array}{r}-0,4729 \\
0,0092\end{array}$ & $\begin{array}{l}1,0000 \\
0,0000\end{array}$ & & & & & \\
\hline $\mathrm{Y}_{5}$ & $\begin{array}{l}\mathrm{r} \\
\mathrm{n}\end{array}$ & $\begin{array}{l}0,3746 \\
0,0244\end{array}$ & $\begin{array}{l}0,2812 \\
0,0096\end{array}$ & $\begin{array}{r}-0,4090 \\
0,0132\end{array}$ & $\begin{array}{r}-0,3898 \\
0,0187\end{array}$ & $\begin{array}{l}1,0000 \\
0,0000\end{array}$ & & & & \\
\hline $\mathrm{Y}_{6}$ & $\begin{array}{l}\mathrm{r} \\
\mathrm{n}\end{array}$ & $\begin{array}{l}0,5142 \\
0,0013\end{array}$ & $\begin{array}{l}0,2582 \\
0,1283\end{array}$ & $\begin{array}{r}-0,6387 \\
0,0001\end{array}$ & $\begin{array}{r}-0,5873 \\
0,0002\end{array}$ & $\begin{array}{l}0,4092 \\
0,0132\end{array}$ & $\begin{array}{l}1,0000 \\
0,0000\end{array}$ & & & \\
\hline $\mathrm{Y}_{7}$ & $\begin{array}{l}\mathrm{r} \\
\mathrm{n}\end{array}$ & $\begin{array}{l}0,5045 \\
0,0017\end{array}$ & $\begin{array}{l}0,2783 \\
0,1002\end{array}$ & $\begin{array}{r}-0,6701 \\
0,0001\end{array}$ & $\begin{array}{r}-0,5876 \\
0,0002\end{array}$ & $\begin{array}{l}0,4705 \\
0,0038\end{array}$ & $\begin{array}{l}0,9355 \\
0,0001\end{array}$ & $\begin{array}{l}1,0000 \\
0,0000\end{array}$ & & \\
\hline $\mathrm{Y}_{8}$ & $\begin{array}{l}\mathrm{r} \\
\mathrm{n}\end{array}$ & $\begin{array}{l}0,1352 \\
0,4315\end{array}$ & $\begin{array}{r}-0,1690 \\
0,3245\end{array}$ & $\begin{array}{r}-0,0570 \\
0,7409\end{array}$ & $\begin{array}{r}-0,4011 \\
0,0153\end{array}$ & $\begin{array}{l}0,1685 \\
0,3259\end{array}$ & $\begin{array}{l}0,5847 \\
0,0002\end{array}$ & $\begin{array}{l}0,5722 \\
0,0003\end{array}$ & $\begin{array}{l}1,0000 \\
0,0000\end{array}$ & \\
\hline $\mathrm{Y}_{9}$ & $\begin{array}{l}\mathrm{r} \\
\mathrm{n}\end{array}$ & $\begin{array}{l}0,2895 \\
0,0867\end{array}$ & $\begin{array}{l}0,0436 \\
0,8006\end{array}$ & $\begin{array}{r}-0,2552 \\
0,1329\end{array}$ & $\begin{array}{r}-0,3292 \\
0,0499\end{array}$ & $\begin{array}{l}0,2456 \\
0,1487\end{array}$ & $\begin{array}{l}0,7350 \\
0,0001\end{array}$ & $\begin{array}{l}0,8190 \\
0,0001\end{array}$ & $\begin{array}{l}0,6316 \\
0,0001\end{array}$ & $\begin{array}{l}1,0000 \\
0,0000\end{array}$ \\
\hline Keterangan: & & $\begin{array}{l}Y_{1}=\text { tinggi } t \\
\text { mur tanaman } \\
\text { anaman; } Y_{8}= \\
=\text { nilai ko } \\
=\text { nilai uji }\end{array}$ & $\begin{array}{l}\text { laman saat be } \\
\text { aat panen per } \\
\text { ekuensi pane } \\
\text { isien korelasi } \\
\text { orelasi }\end{array}$ & $\begin{array}{l}\text { unga; } Y_{2}= \\
\text { na; } Y_{5}=\text { ju } \\
Y_{9}=\text { berat }\end{array}$ & $\begin{array}{l}\text { inggi tanam } \\
\text { lah cabang } p \\
\text { egar buah pe }\end{array}$ & $\begin{array}{l}\text { saar panen } \\
\text { tanaman; Y } \\
\text { ektar }\end{array}$ & $\begin{array}{l}\text { tama; } Y_{3}= \\
\text { jumlah bu }\end{array}$ & $\begin{array}{l}\text { nur tanama } \\
\text { per tanamar }\end{array}$ & $\begin{array}{l}\text { aat berbun } \\
Y_{7}=\text { berat }\end{array}$ & $\begin{array}{l}80 \% ; \mathrm{Y}_{4}= \\
\text { ar buah per }\end{array}$ \\
\hline
\end{tabular}

Menurut Gomez dan Gomez (1995), nilai koefisien korelasi (r) berada antara -1 dan +1 , nilai yang ekstrim $(+1$ dan -1$)$ menunjukkan hubungan yang sempurna dengan arah perubahan yang berbeda, sedangkan nol menunjukkan tidak ada hubungan antara kedua variabel. Nilai $r$ yang positif menunjukkan kedua variabel berubah ke arah yang sama, sebaliknya, jika $r$ bernilai negatif, perubahan positif suatu variabel berhubungan dengan perubahan negatif pada variabel yang lain.

Hasil analisis korelasi terhadap variabelvariabel yang diamati menunjukkan bahwa meningkatnya tinggi tanaman, jumlah cabang per tanaman, jumlah buah per tanaman, berat segar buah per tanaman, dan frekuensi panen akan meningkatkan hasil, yaitu berat segar buah per hektar, namun berdasarkan nilai koefisien korelasi (r) yang diperoleh menunjukkan bahwa variabel frekuensi panen, jumlah buah per tanaman, berat segar buah per tanaman lebih kuat hubungannya dengan berat segar buah per hektar dibandingkan dengan tinggi tanaman dan jumlah cabang. Sebaliknya, semakin lambat umur tanaman saat berbunga $80 \%$ dan saat panen pertama akan menurunkan hasil (berat segar buah) walaupun hubungannya tidak erat karena nilainya lebih dekat kepada nol.

\section{KESIMPULAN}

1. Pengaruh perlakuan pupuk $\mathrm{Zn}$ berbeda nyata terhadap tinggi tanaman dan umur tanaman saat panen pertama, jumlah buah per tanaman, berat segar buah per tanaman, frekuensi panen, dan berat segar buah per hektar, tetapi berbeda tidak nyata terhadap tinggi tanaman saat berbunga, umur tanaman saat berbunga $80 \%$, dan jumlah cabang per tanaman. Perlakuan 4,50 g Zn petak $^{-1}$ setara dengan $6,00 \mathrm{~kg} \mathrm{Zn} \mathrm{ha-1}$ menghasilkan rata-rata berat segar buah tertinggi, yaitu $25,16 \mathrm{Mg} \mathrm{ha}^{-1}$;

2. Pengaruh jarak tanam berbeda nyata terhadap semua variabel pertumbuhan dan hasil yang diamati. Jarak tanam $70 \mathrm{~cm}$ x 50 
cm menghasilkan berat segar buah tertinggi, yaitu $25,18 \mathrm{Mg} \mathrm{ha}^{-1}$;

3. Interaksi antara dosis pupuk $\mathrm{Zn}$ dan jarak tanam berbeda tidak nyata terhadap semua variabel yang diamati;

4. Hasil analisis korelasi menunjukkan bahwa variabel yang berkorelasi nyata dan positif dengan hasil (berat segar buah per hektar) adalah frekuensi panen, jumlah buah per tanaman, dan berat segar buah per tanaman dengan nilai koefisien korelasi (r) berturutturut 0,$6316 ; 0,7350 ;$ dan 0,8190, sedangkan variabel yang berkorelasi negatif dengan hasil (berat segar buah) adalah umur tanaman saat berbunga dan saat panen pertama dengan nilai koefisien korelasi (r) adalah $-0,2552$ dan $-0,3292$.

\section{DAFTAR PUSTAKA}

Alloway, B.J. 2008. Zinc in Soils and Crop Nutrition. Second edition. International Zinc Association (IZA)-International Fertilizer Industry Association (IFA), Brussels and Paris.

Armaini, E. Zuhry, dan G. Sahyoga. 2007. Aplikasi Berbagai Konsentrasi Pupuk Plant Catalyst 2006 dan Giberellin pada Tanaman Tomat (Lycopersicum esculentum Mill.). [Skripsi]. Jurusan Budidaya Pertanian. Fakultas Pertanian. Universitas Riau. [Indonesia].

BPS dan Direktorat Jenderal Hortikultura. Kementerian Pertanian Republik Indonesia. 2020. Data Produksi Sayursayuran dan Buah-buahan di Indonesia Tahun 2015-2019. https://www.pertanian.go.id.

Cahyono, B. 2000. Tomat. Budidaya dan Analisis Usaha Tani. Kanisius, Yogyakarta.

Cahyono, B. 2003. Kacang Buncis. Teknik Budi Daya dan Analisis Usaha Tani. Kanisius. Yogyakarta.
Dwidjoseputro. 2005. Pengantar Fisiologi Tumbuhan. Djambatan, Malang.

Gardner, F.P., R.B. Pearce, dan R.L. Mitchell. 1991. Fisiologi Tanaman Budidaya. Diterjemahkan oleh: Herawati Susilo. Universitas Indonesia Press, Jakarta.

Gomez, K.A. dan A.A. Gomez. 1995. Prosedur Statistik untuk Penelitian Pertanian Edisi Kedua. Diterjemahkan oleh: E. Sjamsuddin dan Justika S. Baharsjah. Ui-Press, Jakarta.

Harjadi, S.S. 2001. Pengantar Agronomi. Gramedia Pustaka Utama, Jakarta.

Hasanuddin, L. Bahri, dan Adrizal. 1999. Analisis pertumbuhan tanaman kedelai pada berbagai varietas, jarak tanam dan pemupukan. Agrista. 3.1 (1999):47-52.

Heddy S. 1996. Hormon Tumbuhan. Raja Grafindo Persada, Jakarta.

Hidayat, N. 2008. Pertumbuhan dan produksi kacang tanah (Arachis hypogea L.) varietas lokal Madura pada berbagai jarak tanam dan dosis pupuk fosfor. Serial online (http://pertanian trunojoyo.ac.id/wp-content /uploads/2013/02/7.-Agrovigor-Sept2008-Vol-1-No-1-Pertumbuhan-danProduksi-Kacang-Tanah-Yayak-.pdf).

Indradewa, D. 2007. Peran Seng (Zn) dalam Budidaya Pertanian sebagai Sumber Pangan dan Dampak Defisiensi Seng dalam Pertanian Global. Prosiding Penanggulangan Masalah Defisiensi Seng (Zn): From Farm to Table. https://repository.ipb.ac.id/jspui/bitstrea $\mathrm{m} / 123456789 / 41998 / 1 /$ prosiding\%20pen anggulangan \%20masalah\%20defisiensi $\% 20$ seng2.pdf.

Jumin, H.B. 2005. Dasar-dasar Agronomi. Grafindo Persada, Jakarta. 
Maddonny. 2013. Pengaruh Jarak Tanam dan Dosis Pupuk Nitrogen Terhadap Pertumbuhan dan Produksi Jagung (Zea mays L.). [Tesis]. Fakultas Pertanian Universitas Andalas, Padang. [Indonesia].

Pendias, A.K. 2011. Trace Elements in Soil and Plant (fourth edition). CRC Press, New York.

Prasetyo, B.H. dan D.A. Suriadikarta. 2006. Karakteristik, potensi, dan teknologi pengelolaan tanah ultisol untuk pengembangan pertanian lahan kering di Indonesia. Litbang Pertanian. 2.25 (2006): 39-47

Rosmarkam, A. dan N.W. Yuwono. 2002. Ilmu Kesuburan Tanah. Kanisius, Yogyakarta.

Salisbury, F.B. dan C.W. Ross. 1995. Fisiologi Tumbuhan Jilid 1. Diterjemahkan oleh: Diah R. Lukman dan Sumaryono. ITB, Bandung.

Sarpian, T. 2003. Pedoman Berkebun Lada dan Analisis Usaha Tani. Kanisius. Yogyakarta.

Sastra, D.R. Analisis keragaman genetik garut (Marantha arundinaceae L.) berdasarkan penanda molekular RAPD. Jurnal Sains dan Teknologi Indonesia. 5.5 (2003): 17-19.
Soepardi, G. 1983. Dasar-dasar Ilmu Tanah. IPB, Bogor.

Sudarmi. Pentingnya unsur hara mikro bagi pertumbuhan tanaman. Jurnal Fakultas Pertanian Universitas Veteran Bangun Nusantara Sukoharjo. 22.5 (2013): 178183.

Sudiarso. 2017. Zinc Terbukti Mampu Meningkatkan Hasil Tanaman. http://sahabatpetani.com/2017/11/08/zin k-terbukti-mampu-meningkatkan-hasilpanen/.

Sulthon, A.M., A.T. Sakya, dan Sulanjari. 2018. Analisis Pertumbuhan Tomat pada Aplikasi Zn Melalui Daun. Makalah Seminar Nasional dalam rangka Dies Natalis UNS ke-42 Tahun 2018 "Peran Keanekaragaman Hayati untuk Mendukung Indonesia sebagai Lumbung Pangan Dunia”.

Susanto. 1994. Tanaman Kakao Budidaya dan Pengelohan Hasil. Kanisius. Yogyakarta.

Sutedjo, M.M. 2006. Pupuk dan Cara Penggunaan. Rineka Cipta, Jakarta.

Taiz, L. and E. Zeiger. 1998. Plant Physiology. The Benjamin/Cummings Publishing Company Inc. Redwood City, California. 